https://doi.org/10.19195/0524-4544.330.6

\author{
TOMASZ DOLATA
}

ORCID: 0000-0003-2028-0671

Uniwersytet Wrocławski

tomasz.dolata@uwr.edu.pl

\title{
O problemie ochrony niemieckich praw własności intelektualnej w Polsce w pierwszych latach po II wojnie światowej
}

Agresja III Rzeszy na Polskę rozpoczęła największą i najstraszliwszą wojnę w dziejach ludzkości. Jej skutki dotknęły wszystkich sfer życia społecznego, nie wyłączając oczywiście przestrzeni prawnej, w tym tej należącej do prawa własności intelektualnej. Niemcy bezwzględnie i bez jakiegokolwiek poszanowania dla istniejących regulacji korzystali z praw autorskich czy patentowych obywateli kolejno podbijanych państw ${ }^{1}$. Po zakończeniu II wojny światowej społeczność międzynarodowa stanęła w związku z tym przed problemem jak najszybszego przywrócenia praw własności intelektualnej mocno naruszonej przez bezprawną aktywność agresorów. Mówiąc o przywracaniu praw własności intelektualnej, mamy na myśli dwa główne zagadnienia: po pierwsze, problematykę eksploatacji praw patentowych (wynalazczych), po drugie - praw autorskich ${ }^{2}$.

Na tym tle ciekawie wyglądają działania władz Polski Ludowej w zakresie prób nowego uregulowania niemieckich ${ }^{3}$ praw własności intelektualnej w pierw-

1 Polityka niemieckiego okupanta w zakresie własności intelektualnej to bardzo ciekawy obszar badawczy, pozostający jednak poza zakresem tej pracy.

${ }^{2}$ Na poziomie ponadpaństwowym większą aktywność społeczność międzynarodowa wykazywała w zakresie prób unormowania praw patentowych niż praw autorskich. Zob. np. projekt porozumienia międzynarodowego o przywróceniu praw własności przemysłowej, „Wiadomości Urzędu Patentowego" 1946, z. 4, s. 112-113; projekt porozumienia o zachowaniu lub przywróceniu praw własności przemysłowej, dotkniętych przez drugą wojnę światową, wraz z obszerną notą wyjaśniającą, „Wiadomości Urzędu Patentowego” 1946, z. 8, s. 191-196; Porozumienie Neuchatelskie z dnia 8 lutego 1947 roku o zachowaniu lub przywróceniu praw własności przemysłowej, dotkniętych przez drugą wojnę światową, „Wiadomości Urzędu Patentowego” 1947, z. 2, s. 26-28.

3 W rozumieniu praw własności intelektualnej przysługujących obywatelom niemieckim. 
szych kilku latach po zakończeniu wojny ${ }^{4}$. Działania te odtwarzamy przede wszystkim na podstawie dokumentacji Ministerstwa Sprawiedliwości zawartej w zasobach Archiwum Akt Nowych (nr zespołu 285, sygn. teczki 2243).

Na poziomie instytucjonalnym problem związany z ewentualną możliwością swobodnego używania niemieckich praw patentowych i autorskich zainicjował Instytut Badawczy Budownictwa ${ }^{5}$, którego członkowie w piśmie do Ministra Odbudowy z dnia 24 kwietnia 1946 roku zauważyli potrzebę jak najszybszego wykorzystywania niemieckich praw własności intelektualnej w procesie wprowadzania szeroko rozumianego postępu technicznego i gospodarczego w Polsce ${ }^{6}$. Instytut w szczególności podkreślał, że odbudowa kraju była bardzo utrudniona z powodu nieistnienia literatury technicznej w języku polskim, spowodowanym przez działania wojenne. Wyszkolenie nowych sił fachowych wymagało czasu, którego brakowało „na drodze do odbudowy i postępu”. Wszystko to postawiło polski świat techniczny w niezwykle trudnej sytuacji. Powstała konieczność przyswojenia opracowań obcych, zwłaszcza niemieckich. Obowiązujące uregulowania międzynarodowego prawa autorskiego utrudniały ten proces, gdyż odszukanie autorów dzieł niemieckich, a następnie porozumienie się z nimi, zadanie to bardzo opóźniłoby lub nawet uniemożliwiłoby ${ }^{7}$. Jak jednak pisali autorzy pisma do Ministerstwa Odbudowy,

sposób prowadzenia wojny przez Niemców, pogwałcenie przez nich wszelkich międzynarodowych praw, rozmyślne i planowe wyniszczenie przez nich wszystkiego, co polskie, w szczególności wszelkich wytworów ducha polskiego, jest dostatecznym powodem do wydania w Polsce ustawy zawieszającej prawa autorskie dla autorów narodowości niemieckiej i w ten sposób zezwolenie właściwym czynnikom polskim do nieskrępowanego korzystania z dzieł niemieckich i dowolnego ich tłumaczenia bez uzyskania zgody autorów — Niemców.

Zdaniem autorów pisma podobnie rzecz się przedstawiała w dziedzinie patentów na wynalazki, przysługujących obywatelom niemieckim. Wykorzystywanie patentów niemieckich również znacznie ułatwiłoby proces odbudowy kraju. W konkluzji Instytut Badawczy Budownictwa prosił Ministra Odbudowy o ,przedłożenie na Krajową Radę Narodową wniosku w sprawie wydania ustawy zawiesza-

${ }^{4}$ Chodzi o drugą połowę lat czterdziestych XX wieku.

5 Geneza Instytutu sięga II RP, kiedy to działał on pod inną nazwą, natomiast już w 1947 roku otrzymał nazwę Instytutu Techniki Budowlanej, pod którą funkcjonuje do dziś.

${ }^{6}$ O potrzebie przejęcia praw własności intelektualnej obywateli niemieckich na rzecz państw-ofiar hitlerowskiej agresji wojennej wypowiadali się również przedstawiciele ówczesnej nauki polskiej. Przykładowo dr Józef Świdrowski, przedwojenny asystent Szkoły Głównej Handlowej w Warszawie, w miesięczniku poświęconym zagadnieniom wiedzy i życia zatytułowanym „Problemy” pisał: „Przez wywłaszczenie z praw autorskich i patentów Niemcy odczują wszystkie przykrości złodzieja, któremu generalnie nie udała się jego akcja i który konsekwentnie musi ponieść skutki swego amoralnego postępowania" - idem, Nowa propozycja w sprawie odszkodowań, „Problemy” 1946, nr 2 (3), s. 62.

${ }^{7}$ Biorąc pod uwagę spore prawdopodobieństwo odmowy udzielenia zgody przez niemieckich właścicieli praw autorskich. 
jącej w Polsce prawo autorskie i patentowe dla autorów i wynalazców narodowości niemieckiej"s.

Dnia 29 maja 1946 roku Ministerstwo Odbudowy przesłało odpis wskazanego pisma Instytutu Badawczego Budownictwa do Ministerstwa Spraw Zagranicznych i Ministerstwa Sprawiedliwości z prośbą o zajęcie stanowiska w zakresie zawartych w nim postulatów. Sprawę określono jako pilną z punktu widzenia odbudowy kraju?

Ministerstwo Spraw Zagranicznych przesłało otrzymany odpis pisma Instytutu Badawczego Budownictwa wraz ze swoim pismem przewodnim do: Ministra Przemysłu, Państwowego Urzędu Patentowego, Ministerstwa Kultury i Sztuki oraz Ministra Sprawiedliwości z prośbą o przedstawienie stanowiska tych instytucji w sprawie zawieszenia praw autorskich i patentowych Niemców ${ }^{10}$. W piśmie przewodnim Ministerstwo Spraw Zagranicznych z jednej strony przedstawiło stan prawa międzynarodowego (zakazującego zawieszenia praw Niemców z uwagi na postanowienia nr 5 Sojuszniczej Rady Kontroli w Berlinie z dnia 30 października 1945 roku), z drugiej zaś — powołało się na opinię prof. dra Juliana Makowskiego ${ }^{11}$ (zwolennika zawieszenia niemieckich praw własności intelektualnej). J. Makowski podkreślił w swojej opinii, że ochrona niemieckiej własności przemysłowej w Polsce opierała się na postanowieniach konwencji związkowej paryskiej o ochronie własności przemysłowej z 1883 roku w redakcji waszyngtońskiej (z 1911 roku $)^{12}$, a ochrona praw autorskich na konwencji berneńskiej o ochronie dzieł literackich i artystycznych z 1886 roku w redakcji rzymskiej (z 1928 roku) ${ }^{13}$. Nadto zauważył, iż powszechnie obowiązującą w prawie międzynarodowym była reguła, zgodnie

8 Pismo Instytutu Badawczego Budownictwa nr 593/46 z dnia 24 kwietnia 1946 roku do Ministra Odbudowy - AAN, Ministerstwo Sprawiedliwości w Warszawie, nr zespołu 285, sygn 2243. Wszystkie cytowane w niniejszym artykule pisma archiwalne pochodzą ze wskazanego zbioru.

9 Pismo przewodnie Ministerstwa Odbudowy L. dz. G.M./1119/46 z dnia 29 maja 1946 roku do Ministerstwa Sprawiedliwości.

10 Pismo Ministerstwa Spraw Zagranicznych nr 551/5866/46 z dnia 22 czerwca 1946 roku w sprawie praw autorskich i patentowych Niemców.

11 Julian Makowski (1875-1959) — prawnik i dyplomata, specjalista prawa międzynarodowego, przedwojenny profesor i rektor Szkoły Głównej Handlowej.

12 Właściwie rzecz ujmując, bezpośrednio po II wojnie światowej Polska związana była tekstem konwencji paryskiej w redakcji haskiej (z 1925 roku); szerzej zob. Stan Międzynarodowego Związku Ochrony Własności Przemysłowej w dniu 1 stycznia 1946 r., „Wiadomości Urzędu Patentowego" 1946, z. 2, s. 71 . Z tego samego zestawienia wynika, że w zakresie ochrony własności przemysłowej Niemcy (od 1 sierpnia 1938 roku) obowiązywał tekst tej samej konwencji w redakcji londyńskiej (z 1934 roku).

13 O konwencjach międzynarodowych w zakresie prawa własności intelektualnej pisali m.in. J. Błeszyński, Konwencja berneńska a polskie prawo autorskie, Warszawa 1979; idem, Ostatnie redakcje konwencji berneńskiej o ochronie dzieł literackich i artystycznych a prawo wewnętrzne, „Zeszyty Naukowe Uniwersytetu Jagiellońskiego” 1977, nr 4, s. 9-48; W. Tabor, E. Traple, Konwencja paryska o ochronie własności przemystowej w świetle tekstu sztokholmskiego, „Zeszyty Naukowe Uniwersytetu Jagiellońskiego" 1977, nr 1, s. 11-50. 
z którą wojna między państwami powodowała ipso facto rozwiązanie wszelkich łączących je umów. Jak wiadomo, Polska od 1 września 1939 roku pozostawała w stanie wojny z Niemcami, dlatego też nie istniała u nas (zdaniem uczonego) ochrona praw własności Niemców na dobrach niematerialnych. Rząd polski powinien według J. Makowskiego wydać oświadczenie, które zostałoby opublikowane w Dzienniku Ustaw, stwierdzające, że stosunek prawny łączący w tej dziedzinie Polskę z Niemcami wygasł 1 września 1939 roku właśnie wskutek wojny. Konkludując, należy wskazać, że zdaniem J. Makowskiego zawieszenie niemieckich praw autorskich i patentowych mogło nastąpić niezależnie od postanowień Sojuszniczej Rady Kontroli ${ }^{14}$.

O ile stanowisko Ministerstwa Spraw Zagranicznych w sprawie zawieszenia niemieckich praw autorskich i patentowych było dość jednoznaczne, o tyle Ministerstwo Sprawiedliwości miało w tej kwestii pewne wątpliwości. W zasobach AAN znajdują się bowiem sprzeczne w swej treści odręczne notatki ${ }^{15}$, które sądząc po charakterze pisma autorów, sporządzone zostały przez dwóch różnych urzędników Ministerstwa Sprawiedliwości. Z jednej notatki, kierowanej do Ministerstwa Spraw Zagranicznych, którą 1 lipca 1946 roku przygotował Dyrektor Departamentu Ustawodawczego w Ministerstwie Sprawiedliwości, wynika, że ministerstwo to uważa za dopuszczalne wydanie dekretu o zawieszeniu w Polsce praw autorskich i patentowych autorów i wynalazców narodowości niemieckiej ${ }^{16}$. Z kolei autor drugiej notatki (z 2 lipca 1946 roku, adresowanej do Ministerstwa Odbudowy), powołując się na traktaty międzynarodowe, zawiadamia, że Ministerstwo Sprawiedliwości nie widzi możliwości wydania „wewnętrznej ustawy” zawieszającej prawa autorskie dla autorów narodowości niemieckiej ${ }^{17}$. Jak się jednak wydaje, ten pierwszy pogląd stał się oficjalnym stanowiskiem Ministerstwa Sprawiedliwości.

Wracając do korespondencji i ustaleń między poszczególnymi resortami, trzeba wskazać, że Ministerstwo Spraw Zagranicznych pismem z dnia 30 sierpnia 1946 roku zakomunikowało Ministerstwu Odbudowy, że nie zgłasza zastrzeżeń do inicjatywy zawieszenia w Polsce praw autorskich i patentowych autorów i wynalazców niemieckich w drodze ustawodawczej ${ }^{18}$. Podobne stanowisko przesłało Ministerstwu Odbudowy w dniu 21 września 1946 roku Ministerstwo Sprawiedliwości.

Do pewnego momentu sprawa praw autorskich i wynalazczych przysługujących obywatelom niemieckim, zainicjowana przez Instytut Badawczy Budownictwa w kwietniu 1946 roku, prowadzone były niejako równolegle. Sytuacja ta

14 Przytoczenie w piśmie przewodnim opinii J. Makowskiego sugeruje, że Ministerstwo Spraw Zagranicznych przychylało się do prezentowanego przez tego uczonego poglądu.

15 Stanowiące projekty pism.

16 Dokument w rękopisie.

17 Dokument w rękopisie.

18 Pismo Ministerstwa Spraw Zagranicznych w sprawie praw autorskich i patentowych Niemców nr 551/6435.E/10516/46 z dnia 30 sierpnia 1946 roku do Ministerstwa Odbudowy. 
zmieniła się w październiku 1946 roku, kiedy Ministerstwo Spraw Zagranicznych dostrzegło możliwość uregulowania niemieckich praw wynalazczych na podstawie przepisów umów międzynarodowych. W dniu 10 października 1946 roku ministerstwo to w załączeniu do swojego pisma nr 375/11575.E/12294/46, skierowanego do: Komitetu Ekonomicznego Rady Ministrów, Ministerstwa Przemysłu, Urzędu Patentowego, Biura Rewindykacji i Odszkodowań Wojennych przy Centralnym Urzędzie Planowania, Ministerstwa Odbudowy oraz Ministerstwa Komunikacji, przesłało adresatom tłumaczenie tak zwanego układu londyńskiego dotyczącego patentów niemieckich ${ }^{19}$ wraz z tekstem dodatkowo uchwalonych rezolucji. Jednocześnie Ministerstwo Spraw Zagranicznych poprosiło wskazane podmioty o jak najszybsze sprecyzowanie stanowiska w sprawie celowości przystąpienia Polski do tego układu ${ }^{20}$. Nadto ministerstwo zwracało uwagę, że ewentualne przystąpienie Polski do układu uczyniłoby bezprzedmiotową inicjatywę Ministerstwa Odbudowy w sprawie zawieszenia skuteczności niemieckich praw patentowych w Polsce ${ }^{21}$.

W związku z tym Ministerstwo Odbudowy pismem z dnia 4 listopada 1946 roku zwróciło się do Ministerstwa Sprawiedliwości z prośbą o wystąpienie z inicjatywą ustawodawczą w przedmiocie zawieszenia niemieckich praw autorskich. Co do niemieckich praw patentowych Ministerstwo Odbudowy uznało, że kwestia ta może zostać rozwiązana drogą przystąpienia przez Polskę do regulującego tę problematykę wspomnianego już układu londyńskiego ${ }^{22}$. Zgodnie bowiem z art. 1 porozumienia londyńskiego wszystkie patenty, które należały do Niemców, miały zostać „oddane do użytku publicznego lub na rzecz dobra publicznego"23 albo na wykonywanie tych patentów miały być udzielane bezpłatne licencje dla obywateli wszystkich państw będących uczestnikami tego porozumienia.

W dniu 23 listopada 1946 roku w Ministerstwie Przemysłu miała się odbyć konferencja w sprawie celowości przystąpienia Polski do układu londyńskiego z dnia 27 lipca 1946 roku $^{24}$. W dokumentacji Ministerstwa Sprawiedliwości zawartej w zasobach Archiwum Akt Nowych nie ma jednak informacji o przebie-

19 Porozumienie z dnia 27 lipca 1946 roku w sprawie patentów na wynalazki, których właścicielami byli Niemcy, „Wiadomości Urzędu Patentowego” 1946, z. 9-10, s. 211-212.

20 Zgodnie bowiem $\mathrm{z}$ art. 8 porozumienia londyńskiego układ pozostawał otwarty do podpisania przez inne państwa do dnia 31 grudnia 1946 roku.

${ }^{21}$ Pismo Ministerstwa Spraw Zagranicznych w sprawie niemieckich praw patentowych nr 375/11575.E/12294/46 z dnia 10 października 1946 roku do Komitetu Ekonomicznego Rady Ministrów, Ministerstwa Przemysłu, Urzędu Patentowego, Biura Rewindykacji i Odszkodowań Wojennych przy Centralnym Urzędzie Planowania, Ministerstwa Odbudowy oraz Ministerstwa Komunikacji.

22 Pismo Ministerstwa Odbudowy w sprawie zawieszenia niemieckich praw autorskich i patentowych w Polsce L.dz. G.M. 1119,2500,2834/W2/46 z dnia 4 listopada 1946 roku do Ministerstwa Sprawiedliwości.

${ }^{23} \mathrm{~W}$ oryginale public domain.

24 Pismo Ministerstwa Przemysłu BP.II/378/6573/46/JO z dnia 18 listopada 1946 roku do Ministerstwa Sprawiedliwości. 
gu i konkluzjach wynikających z tej konferencji. Niemniej władze zdecydowały o przystąpieniu Polski do umowy londyńskiej w sprawie patentów na wynalazki, których właścicielami byli Niemcy ${ }^{25}$. Tym sposobem problem korzystania z niemieckich praw wynalazczych po II wojnie światowej w Polsce został rozwiązany.

Nadal nieuregulowana pozostawała jednak kwestia niemieckich praw autorskich. Dlatego też w Ministerstwie Sprawiedliwości trwały prace nad przepisami, których celem miało być umożliwienie stronie polskiej swobodnego z nich korzystania w procesie odbudowy kraju. Efekt tych prac stanowił projekt dekretu o częściowym uchyleniu zastosowania prawa autorskiego do dzieł techniczno-naukowych autorów niemieckich (UR 470/46) ${ }^{26}$.

W dniu 2 stycznia 1947 roku w Ministerstwie Sprawiedliwości zebrała się Komisja Prawnicza ${ }^{27}$ w sprawie omówienia zasad tegoż projektu dekretu. Posiedzeniu przewodniczył i protokołował je Witold Czachórski ${ }^{28}$ (w tamtym czasie pracownik Departamentu Ustawodawczego Ministerstwa Sprawiedliwości). Po odczytaniu projektu poprosił członków Komisji o opinię co do zasad ogólnych zawartych w projekcie. Przedstawiciele Ministerstwa Odbudowy i Instytutu Badawczego Budownictwa zgodnie oświadczyli, że wydanie aktu prawnego w przedmiocie zawieszenia praw autorskich autorów niemieckich było niezbędne. Do stanowiska tego przyłączyli się następnie przedstawiciele Ministerstwa Przemysłu i Ministerstwa Ziem Odzyskanych. Z kolei przedstawiciel Ministerstwa Informacji i Propagandy oświadczył, iż zgodnie z zasadami prawa międzynarodowego umowy międzynarodowe wygasają wskutek wojny, dlatego należało przyjąć do wiadomości stan polegający na całkowitym braku ochrony praw autorskich autorów niemieckich na

25 Zob. porozumienie z dnia 27 lipca 1946 roku w sprawie patentów na wynalazki, których właścicielami byli Niemcy (Przystąpienia), „Wiadomości Urzędu Patentowego” 1947, z. 2, s. 28.

26 Projekt dekretu o częściowym uchyleniu zastosowania prawa autorskiego do dzieł techniczno-naukowych autorów niemieckich, UR 470/46, dokument w rękopisie: „Art. 1. W związku z koniecznością odbudowy kraju, zniszczonego w czasie działań wojennych w latach 1939-1945, Minister Odbudowy może zezwolić na wydanie w języku polskim określonych dzieł techniczno-naukowych autorów niemieckich, z pominięciem szczególnych przepisów prawa autorskiego. Art. 2. Przepis art. poprzedzającego ma zastosowanie jedynie w odniesieniu do dzieł mających znaczenie dla celów odbudowy kraju i jego struktury na terytorium Państwa Polskiego. Art. 3. Wykonanie niniejszego dekretu porucza się Min. Odbudowy. Art. 4. Dekret niniejszy wchodzi w życie z dniem ogłoszenia". Uzasadnienie projektu tego dekretu zaczerpnięte (przepisane) zostało z przywołanego wcześniej pisma Instytutu Badawczego Budownictwa z dnia 24 kwietnia 1946 roku skierowanego do Ministerstwa Odbudowy. Pismo to, przypomnijmy, zainicjowało aktywność Ministerstwa Odbudowy i w konsekwencji innych ministerstw w procesie starań o swobodne korzystanie z niemieckich praw autorskich i patentowych.

27 W skład tej Komisji weszli (po jednym) przedstawiciele: Ministerstwa Sprawiedliwości (przewodniczący i zarazem protokolant), Ministerstwa Skarbu, Ministerstwa Odbudowy, Ministerstwa Przemysłu, Ministerstwa Informacji i Propagandy, Ministerstwa Ziem Odzyskanych, Instytutu Badawczego Budownictwa. Na posiedzeniu w dniu 2 stycznia 1947 roku zabrakło przedstawicieli Ministra Kultury i Sztuki oraz Biura Przewodniczącego Prezydium Rady Ministrów.

28 Witold Czachórski (1915-1995) — późniejszy wybitny polski cywilista, profesor nauk prawnych. 
terytorium państwa polskiego. W związku z tym wydawanie specjalnego dekretu w tej sprawie uznał za zbędne. Podkreślił okoliczność, że jeśli dowolna firma wydawnicza chciałaby dokonać tłumaczenia dzieł niemieckich, może to swobodnie uczynić. Następnie głos zabrał przewodniczący Komisji - przedstawiciel Ministerstwa Sprawiedliwości, który poparł stanowisko przedmówcy, jednocześnie zaznaczając, że wydanie dekretu miałoby swoje plusy. Sugerował, iż należałoby zastanowić się, czy nie można by osiągnąć tego samego skutku w drodze innego aktu niż dekret (na przykład przez wydanie oświadczenia przez rząd lub przez jednego z ministrów, a następnie opublikowanie tego oświadczenia w odpowiednim publikatorze). W odpowiedzi przedstawiciel Ministerstwa Odbudowy odparł, że dla jego ministerstwa obojętne jest, czy sprawa zostanie załatwiona w formie dekretu, czy innego aktu, najważniejsze byleby nastąpiła publikacja tego aktu prawnego. Kolejną osobą, która się wypowiedziała, był przedstawiciel Ministerstwa Skarbu. Nie zgłosił on sprzeciwu co do zasad dekretu, jednak zastrzegł, że gdyby dekret miał spowodować jakiekolwiek świadczenia ze strony Skarbu Państwa (na przykład w formie odszkodowań dla autorów niemieckich), musiałby wnosić o odroczenie posiedzenia w celu zajęcia stanowiska ad meritum. Odpowiedział mu przedstawiciel Ministerstwa Odbudowy, zaznaczając, że ewentualne roszczenia autorów niemieckich przeciwko państwu polskiemu będą podstawą przyszłych rozliczeń reparacyjnych, ale to problem na przyszłość.

W dalszej części posiedzenia przewodniczący Komisji skierował dyskusję na omówienie szczegółowych rozwiązań projektu. Najpierw głos zabrał przedstawiciel Instytutu Badawczego Budownictwa, który za zbyt wąskie uznał ramy zawieszenia praw autorskich oraz konieczność wydawania zezwoleń (art. 1 projektu). Sugerował, że być może wystarczyłoby tylko zarejestrowanie tłumaczeń w jakiejś instytucji, względnie w Ministerstwie Odbudowy. Przedstawiciel tego ministerstwa wypowiedział się z kolei za pozostawieniem rozwiązań dotyczących zezwoleń na tłumaczenia, ale uznał za celowe skreślenie jako zbędnych w projekcie dekretu: wyrazu „określonych” w art. 1 i zwrotu „mających znaczenie dla celów odbudowy kraju" w art. 2. Przedstawiciel Ministerstwa Odbudowy opowiedział się więc za znacznym rozszerzeniem możliwości wydawania dzieł niemieckich w języku polskim z pominięciem praw autorskich. Następny mówca — delegat Ministerstwa Przemysłu — uznał natomiast za właściwe rozciągnięcie rozwiązań zawartych $\mathrm{w}$ art. 1 także na dzieła dotyczące produkcji przemysłowej oraz postulował powierzenie spraw udzielania zezwoleń również Ministrowi Przemysłu. O wiele dalej poszedł przedstawiciel Instytutu Badawczego Budownictwa, który stwierdził, że właściwie należałoby rozważyć rozszerzenie dekretu na przedmiot zainteresowania Ministerstwa Komunikacji i ewentualnie innych jeszcze ministerstw, jak też wydawnictw naukowych, niekoniecznie ściśle technicznych. Ponadto instytucja wydająca zezwolenia powinna być scentralizowana, dlatego być może sprawę należałoby przekazać na przykład Komitetowi Ekonomicznemu Rady Ministrów. W odpowiedzi na tę wymianę zdań przewodniczący Komisji 
stwierdził, że na gruncie sformułowań zawartych w omawianym projekcie powstały istotne spory merytoryczne, w związku z czym wniósł o odroczenie obrad Komisji. W rezultacie Komisja postanowiła posiedzenie odroczyć i zobowiązać Ministerstwo Odbudowy do złożenia wniosków merytorycznych co do szczegółowych koncepcji dekretu w terminie dwóch tygodni ${ }^{29}$.

W ramach realizacji wymienionych postanowień Komisji Prawniczej Ministerstwo Odbudowy 18 stycznia 1947 roku wystosowało do Departamentu Ustawodawczego Ministerstwa Sprawiedliwości odpowiedź, w której podniesiono, że projekt rozpatrywanego dekretu w art. 1 warunkował wydawanie w języku polskim określonych dzieł techniczno-naukowych autorów niemieckich od zgody Ministra Odbudowy. Ministerstwo Odbudowy wypowiedziało się przeciwko takiemu rozwiązaniu. W opinii tego ministerstwa wydawanie $\mathrm{w}$ języku polskim prac autorów niemieckich nie powinno być uzależnione od zezwolenia, a problem ten mógł być pozostawiony inicjatywie rynku wydawniczego. W związku z tym Ministerstwo Odbudowy wycofało swoje poparcie dla projektu dekretu w takiej treści i zaproponowało dwa alternatywne rozwiązania. Pierwszym miało być wydanie w tym zakresie opublikowanego w Dzienniku Ustaw oświadczenia rządowego o wygaśnięciu 1 września 1939 roku mocy obowiązującej traktatów międzynarodowych łączących Polskę z Niemcami, co pociągnęłoby za sobą również wygaśnięcie zobowiązań wynikających z konwencji berneńskiej (pokrywało się to z przytoczoną wcześniej opinią prof. Makowskiego). Drugim rozwiązaniem według ministerstwa miało być wprowadzenie do obrotu prawnego dekretu o częściowym uchyleniu zastosowania prawa autorskiego do dzieł techniczno-naukowych autorów niemieckich, który nie zawierałby klauzuli uzależniającej wydawanie dzieł autorów niemieckich w języku polskim od zezwolenia władzy. Decyzję, które rozwiązanie należałoby zastosować, Ministerstwo Odbudowy pozostawiło Ministerstwu Sprawiedliwości w porozumieniu z Ministerstwem Spraw Zagranicznych ${ }^{30}$.

W konsekwencji 19 lutego 1947 roku Ministerstwo Sprawiedliwości zawiadomiło dwa najbardziej zainteresowane i aktywne w tej sprawie resorty, czyli Ministerstwo Spraw Zagranicznych i Ministerstwo Odbudowy, że wobec zmiany stanowiska (wycofania poparcia) przez Ministerstwo Odbudowy w stosunku do projektu dekretu o częściowym uchyleniu zastosowania prawa autorskiego do dzieł techniczno-naukowych autorów niemieckich Ministerstwo Sprawiedliwości uważa ten projekt za nieuzgodniony merytorycznie i usuwa go z porządku obrad Komisji Prawniczej ${ }^{31}$.

29 Protokół posiedzenia Komisji Prawniczej z dnia 2 stycznia 1947 roku w sprawie UR 470/46.

30 Pismo Ministerstwa Odbudowy L.dz. G.M.4196/W2/46 w sprawie uchylenia zastosowania prawa autorskiego do dzieł techniczno-naukowych autorów niemieckich z dnia 18 stycznia 1947 roku do Ministerstwa Sprawiedliwości.

31 Pismo Ministerstwa Sprawiedliwości z dnia 19 stycznia 1947 roku dotyczące pisma G.M.4196/W2/46 Ministerstwa Odbudowy do Ministerstwa Spraw Zagranicznych i Ministerstwa Odbudowy. 
Gdy wydawało się już, że sprawa niemieckich praw autorskich w Polsce została zamknięta, Ministerstwo Odbudowy podjęło kolejną inicjatywę załatwienia tej kwestii. Pismem z dnia 17 marca 1947 roku poprosiło bowiem Ministerstwo Spraw Zagranicznych o przystąpienie do uregulowania tej problematyki drogą oświadczenia rządowego stwierdzającego wygaśnięcie konwencji berneńskiej i wynikających z niej zobowiązań Polski. W piśmie tym Ministerstwo Odbudowy ponownie powołało się na powagę tego zagadnienia z punktu widzenia odbudowy kraju oraz podkreśliło konieczność jak najszybszego umożliwienia korzystania z dzieł autorów niemieckich i dowolnego ich tłumaczenia ${ }^{32}$.

W odpowiedzi Ministerstwo Spraw Zagranicznych pismem z dnia 24 kwietnia 1947 roku wyjaśniło Ministerstwu Odbudowy, że nie uważa za możliwe ogłoszenia oświadczenia rządowego, z którego treści wynikałoby, iż zobowiązania Polski wypływające $\mathrm{z}$ konwencji berneńskiej wygasły względem niemieckich praw autorskich. Dalej Ministerstwo Spraw Zagranicznych podkreśliło, że zawieszenie praw autorskich było możliwe w trybie zarządzenia wojennego do czasu zawarcia traktatu pokojowego z Niemcami ${ }^{33}$. Stanowisko to przystopowało na pewien czas aktywność ministerialną w zakresie uregulowania niemieckich praw autorskich w Polsce. Problem odżył w 1949 roku, gdy Ministerstwo Budownictwa ${ }^{34}$ wystosowało pisemne zapytanie do Ministerstwa Sprawiedliwości i Ministerstwa Spraw Zagranicznych, czy tłumaczenie i wydawanie książek i innych wydawnictw opublikowanych w języku niemieckim w Austrii i Niemczech przed wojną, w czasie wojny i po wojnie - bez porozumienia z autorem lub wydawcą bądź osobą ich prawa reprezentującą — nie naraziłoby na straty polskiego Skarbu Państwa bądź osób prawnych podległych właściwym ministrom ${ }^{35}$. Ministerstwo Sprawiedliwości zakomunikowało Ministerstwu Budownictwa, że zajmie stanowisko w tej sprawie po poznaniu opinii Ministerstwa Spraw Zagranicznych ${ }^{36}$. Nadto, w kolejnym piśmie, Ministerstwo Sprawiedliwości przygotowało odpowiedź dla Ministerstwa Budownictwa, z której wynikało, że na podstawie art. 2 ust. 1 dekretu z dnia 8 marca 1946 roku o majątkach opuszczonych i poniemieckich ${ }^{37}$ wszelki

32 Pismo Ministerstwa Odbudowy G.M.1202/W2/47 w sprawie uchylenia zastosowania prawa autorskiego do dzieł techniczno-naukowych autorów niemieckich z dnia 17 marca 1947 roku do Ministerstwa Spraw Zagranicznych.

33 Szerzej zob. Pismo Ministerstwa Spraw Zagranicznych w sprawie niemieckich praw autorskich nr 375/2147 tjn/SR.E.2923 z dnia 24 kwietnia 1947 roku do Ministerstwa Odbudowy.

34 Ministerstwo Budownictwa (13 maja 1949-1 stycznia 1951) — następca prawny Ministerstwa Odbudowy działającego od 11 czerwca 1945 do 13 maja 1949 roku.

35 Pismo Ministerstwa Budownictwa w sprawie niemieckich praw autorskich nr L.U.R.470-1947 z dnia 11 sierpnia 1949 roku do Ministerstwa Sprawiedliwości; odpis pisma Ministerstwa Budownictwa w sprawie niemieckich praw autorskich na nr 375/2/47/Tajne z dnia 11 sierpnia 1949 roku do Ministerstwa Spraw Zagranicznych.

36 Projekt odpowiedzi Ministerstwa Sprawiedliwości do Ministerstwa Budownictwa (w rękopisie).

37 Dz.U. z 1946 r. Nr 13, poz. 87. 
majątek Rzeszy Niemieckiej i byłego Wolnego Miasta Gdańska oraz obywateli Rzeszy Niemieckiej i byłego Wolnego Miasta Gdańska z mocy samego prawa przeszedł na własność Skarbu Państwa. Wierzytelności pieniężne i inne prawa należne obywatelom Rzeszy Niemieckiej (dotyczyło to także praw wypływających z prawa autorskiego), w myśl art. 2 ust. 7 tego dekretu, uznano za zajęte na rzecz Skarbu Państwa. Natomiast do tych wrogich państw i ich obywateli, do których nie można było zastosować art. 2 dekretu o majątkach opuszczonych i poniemieckich, Ministerstwo Sprawiedliwości jako właściwe wskazywało przepisy dekretu z dnia 15 listopada 1946 roku o zajęciu majątku państw pozostających z Państwem Polskim w stanie wojny w latach 1939-1945 i majątku osób prawnych i obywateli tych państw oraz o zarządzie przymusowym nad tymi majątkami ${ }^{38}$. Poza tym Ministerstwo Sprawiedliwości przypomniało, że Ministerstwo Spraw Zagranicznych w przywoływanym już piśmie do Ministra Odbudowy z dnia 24 kwietnia 1947 roku wyjaśniło, że zawieszenie niemieckich praw autorskich mogłoby być traktowane jako zarządzenie wojenne podjęte przed zawarciem traktatu pokojowego ${ }^{39}$.

Mimo przedstawionego własnego stanowiska stwierdzającego, że prawa autorskie obywateli niemieckich przysługiwały po wojnie państwu polskiemu (Skarbowi Państwa), Ministerstwo Sprawiedliwości w piśmie z września 1949 roku, skierowanym do Ministerstwa Budownictwa, oznajmiło, iż nie można przewidzieć, czy wydanie dzieł niemieckich bez porozumienia się z ich autorami nie spowoduje w przyszłości obowiązku zapłacenia odszkodowania autorowi lub uprawnionemu przez niego wydawcy. Można natomiast zająć jednoznaczne stanowisko co do faktu, że konwencja berneńska o ochronie dzieł literackich i artystycznych, do której przystąpiły Polska i Niemcy, nie obowiązuje w stosunkach polsko-niemieckich (od 1 września 1939 roku) wobec stanu wojny. Ministerstwo Sprawiedliwości nie uważało jednak za wskazane ogłaszania stosownego w tej sprawie komunikatu lub obwieszczenia w Dzienniku Ustaw czy Monitorze Polskim ${ }^{40}$.

Jak widać, problem uregulowania niemieckich praw własności intelektualnej nie został do końca lat czterdziestych XX wieku definitywnie zamknięty. Po wojnie władze polskie zamierzały pozbawić Niemców należnych im praw w tym zakresie, kierując się przede wszystkim chęcią bezzwłocznego wprowadzania rozwiązań mających na celu jak najszybszą odbudowę i postęp techniczny kraju. Jednocześnie działania polegające na eksploatowaniu dorobku intelektualnego obywateli niemieckich, nawet $\mathrm{z}$ ewentualnym pominięciem ich praw, miały być traktowane jako akt sprawiedliwości dziejowej. Co prawda poprzez przystąpienie Polski do porozumienia londyńskiego z 1946 roku udało się usankcjonować prawnie korzystanie z patentów, które należały do Niemców, jednak nie uregulowano

38 Dz.U. z 1946 r. Nr 62, poz. 342.

39 Szerzej zob. projekt odpowiedzi Ministerstwa Sprawiedliwości z dnia 31 sierpnia 1949 roku do Ministerstwa Budownictwa (w rękopisie).

40 Pismo Ministerstwa Sprawiedliwości U.34/tjn/49 C.621 z września 1949 roku do Ministerstwa Budownictwa. 
tego problemu odnośnie do niemieckich praw autorskich. Strona polska stała na stanowisku, że zobowiązania Polski do respektowania praw autorów niemieckich wynikające z postanowień konwencji berneńskiej wygasły wskutek wojny. Nie było niestety pewności, czy swobodne używanie tych praw nie spowoduje w przyszłości obowiązków odszkodowawczych. Nieuregulowanie tej kwestii dowodzi braku spójnej koncepcji i niezdecydowania władz, jak również chyba dowodzi faktu, że prawo autorskie w tamtym ustroju mocno straciło na znaczeniu. W nowych, powojennych realiach nie było ono bowiem tak eksponowane jak w dwudziestoleciu międzywojennym ${ }^{41}$. O degradacji prawa autorskiego pośrednio świadczyć może także to, że ustawodawca polski zdecydował się na wprowadzenie nowej ustawy chroniącej prawa autorskie dopiero w 1952 roku.

\section{Bibliografia}

\section{Archiwalia}

AAN, Ministerstwo Sprawiedliwości w Warszawie, nr zespołu 285, sygn 2243.

\section{Akty prawne}

\section{Krajowe}

Dekret z dnia 8 marca 1946 roku o majątkach opuszczonych i poniemieckich (Dz.U. z 1946 r. $\mathrm{Nr}$ 13, poz. 87).

Dekret z dnia 15 listopada 1946 roku o zajęciu majątku państw pozostających z Państwem Polskim w stanie wojny w latach 1939-1945 i majątku osób prawnych i obywateli tych państw oraz o zarządzie przymusowym nad tymi majątkami (Dz.U. z 1946 r. Nr 62, poz. 342).

\section{Międzynarodowe}

Porozumienie Neuchatelskie z dnia 8 lutego 1947 roku o zachowaniu lub przywróceniu praw własności przemysłowej, dotkniętych przez drugą wojnę światową, „Wiadomości Urzędu Patentowego" 1947, z. 2.

Porozumienie z dnia 27 lipca 1946 roku w sprawie patentów na wynalazki, których właścicielami byli Niemcy, „Wiadomości Urzędu Patentowego” 1946, z. 9-10.

Porozumienie z dnia 27 lipca 1946 roku w sprawie patentów na wynalazki, których właścicielami byli Niemcy (Przystąpienia), „Wiadomości Urzędu Patentowego” 1947, z. 2.

Projekt porozumienia międzynarodowego o przywróceniu praw własności przemysłowej, „Wiadomości Urzędu Patentowego" 1946, z. 4.

Projekt porozumienia o zachowaniu lub przywróceniu praw własności przemysłowej, dotkniętych przez drugą wojnę światową, „Wiadomości Urzędu Patentowego” 1946, z. 8.

${ }^{41}$ Uwaga ta dotyczy zresztą wszystkich przedmiotów wchodzących w zakres prawa własności intelektualnej. 


\section{Literatura}

Błeszyński J., Konwencja berneńska a polskie prawo autorskie, Warszawa 1979.

Błeszyński J., Ostatnie redakcje konwencji berneńskiej o ochronie dziet literackich i artystycznych a prawo wewnętrzne, „Zeszyty Naukowe Uniwersytetu Jagiellońskiego” 1977, nr 4.

Stan Międzynarodowego Związku Ochrony Własności Przemysłowej w dniu 1 stycznia 1946 r., „Wiadomości Urzędu Patentowego” 1946, z. 2.

Świdrowski J., Nowa propozycja w sprawie odszkodowań, „Problemy” 1946, nr 2 (3).

Tabor W., Traple E., Konwencja paryska o ochronie własności przemystowej w świetle tekstu sztokholmskiego, „Zeszyty Naukowe Uniwersytetu Jagiellońskiego” 1977, nr 1.

\section{On the problem of the protection of German intellectual property rights in Poland in the first few years following the Second World War}

\section{Summary}

Right after the end of the Second World War a decision was taken to deal with the problem of patent rights and copyright of German nationals by means of internal (national) regulations. A relevant letter was sent in April 1946 to the Ministry of Reconstruction by the Construction Research Institute. This began a rather lively exchange of correspondence on the ministerial level. Particularly active in it were three ministries: Ministry of Reconstruction, Ministry of Justice and Minister of Foreign Affairs. In the end, however, the problem of the use of patents belonging to German nationals under pre-war international agreements was resolved by means of the London Accord of 27 July 1946 which Poland endorsed in late 1946. What turned to be much more problematic was the regulation of German copyright. The Polish authorities were considering the adoption of the so-called decree on partial revocation of copyright on technical and scientific works by German authors. However, owing to a lack of consent from the various ministries as well as uncertainty about possible future consequences associated with compensation the attempts proved ineffective.

Keywords: intellectual property, copyright, patent law, copyright and patent rights of German nationals after the Second World War

\section{Zur Problematik des Schutzes der deutschen geistigen Eigentumsrechte in den ersten Jahren nach dem Zweiten Weltkrieg in Polen}

\section{Zusammenfassung}

Unmittelbar nach Ende des Zweiten Weltkrieges versuchte man, das Problem der Patent- und der Urheberrechte deutscher Bürger zusammen zu lösen - mittels der internen (Landes-) Vorschriften. Im April 1946 hat das Forschungsinstitut für Bauwesen [Instytut Badawczy Budownictwa] ein Schreiben an das Ministerium für Wiederaufbau [Ministerstwo Odbudowy] gerichtet, was zu einer regen Korrespondenz auf ministerialer Ebene geführt hat. Besonders aktiv waren in dieser Sache drei Ministerien: das Ministerium für Wiederaufbau, Justizministerium und Ministerium für Auswärtige Angelegenheiten. Die Probleme, die mit der Anwendung der Patente verbunden 
waren, die nach den internationalen Vorkriegsabkommen den deutschen Bürgern zustanden, wurden schließlich kraft des Londoner Abkommens vom 27. Juli 1946 über die Behandlung deutscher Patente gelöst, Polen trat diesem Abkommen Ende des Jahres 1946 bei. Wesentlich problematischer war die Regelung der deutschen Urheberrechte. Die polnischen Behörden überlegten nämlich die Herausgabe eines sog. Dekretes über die teilweise Aufhebung der Anwendung des Urheberrechtes in Bezug auf die wissenschaftlich-technischen Werke deutscher Autoren. Da jedoch die einzelnen Ministerien diesem nicht zugestimmt haben und Bedenken hinsichtlich künftiger Schadensersatzfolgen bestanden, hat man davon abgesehen.

Schlüsselwörter: geistiges Eigentum, Urheberrecht, Patentrecht, Urheber- und Patentrechte deutscher Bürger in Polen nach dem Zweiten Weltkrieg 